\title{
Review
}

\section{BCL-2 family members in the development and degenerative pathologies of the nervous system}

\author{
Rémy Sadoul \\ Serono Pharmaceutical Research Institute, 14 chemin des Aulx, 1228 Plan les \\ Ouates, Geneva, Switzerland \\ tel: $41-22-7069710$ \\ e mail: remy.sadoul .ch_gva03@serono.com \\ Received 29.12.97; revised 25.6.98; accepted 2.7.98 \\ Edited by G. Melino
}

\begin{abstract}
Neuronal death is an essential feature in the normal development of the nervous system and in neurodegenerative states of the adult or ageing brain. Bcl-2 is the prototype of a growing family of proteins which control cell death. Many of these proteins are expressed in the nervous system during development and in the adult. Numerous observations have suggested that this family of proteins plays a central role in the control of naturally occurring and pathological neuronal death. In this review, I will discuss the possible mechanisms of action of these proteins as well as their potential use in treating neurodegenerative diseases.
\end{abstract}

Keywords: Bcl-x; Bax; neurodegeneration; apoptosis; neuronal death; mitochondria

Abbreviations: $\mathrm{BH}, \mathrm{Bcl}-2$ homology domain; $\mathrm{Bax}, \mathrm{Bcl}-2$ associated protein $\mathrm{x}$; $\mathrm{CF}$, carboxy fluorescein; CNTF, ciliary neurotrophic factor; BDNF, brain derived neurotrophic factor; NGF, nerve growth factor; NT-3, neurotrophin-3; IGF-1, insulin like growth factor; NOCD, naturally occurring cell death, HSV, herpes simplex virus; CCP, cyanide M-chlorophenyl hydrazone; AD, Alzheimer's disease; PD, Parkinson's disease; ALS, amyotrophic lateral sclerosis; SOD1, superoxide dismutase 1; SMA, spinal muscular atrophy; NAIP, neuron-anti-apoptosis protein; SMN, spinal motor neuron; IAP, inhibitor of apoptosis

\section{Introduction}

For decades, cell death has been recognised by embryologists as an outstanding feature of normal neuronal development (Oppenheim, 1991). Today, it is widely accepted that neurotrophins, electrical activity, hormones or cell contacts stimulate neuronal survival throughout critical periods of the development. One essential role of these survival factors is to block an active cell death program which is initiated by default (Hamburger and Oppenheim, 1982; Raff et al, 1993). Today the term 'programmed cell death' refers to this chain of molecular events which underlies active cell death. As in the embryo, massive cell death also occurs in the adult and ageing nervous system in acute and chronic pathologies referred to as neurodegenerative diseases.

The demonstration that overexpression of the protooncogene $\mathrm{Bcl}-2$ protects neurons from naturally occurring cell death and from a variety of pathological insults has suggested that the control of neuronal death by proteins of the $\mathrm{Bcl}-2$ family is common to development and diseases (Sadoul et al, 1994). These findings have shown that mimicking the effect of Bcl-2 may allow to block neuronal cell death by agents that do not prevent the initial damage nor facilitate its repair. This opens new avenues for the treatment of neurodegenerative diseases for which the causative agents as well as the mechanisms of cell destruction are largely unknown.

The present review summarises results demonstrating the role of $\mathrm{Bcl}-2$ family members in controlling neuronal death and discusses the role that Bcl-2-like proteins may have during development and in acute and chronic diseases.

\section{The Bcl-2 family}

$b c l-2$ was identified at the chromosomal breakpoint of $t(14 ; 18)$ an alteration that occurs in almost all (over 95\%) of human follicular B lymphomas (Tsujimoto et al, 1984). Bcl-2 favours malignancy, not by acting on proliferation per se, but by extending cell survival. Indeed, Bcl-2 extends cell survival by blocking cell death following a variety of signals. (Hockenbery et al, 1990). Bcl-2 is the prototype of a growing family of cytosolic proteins (Figure 1) which includes antiapoptotic members such as Bcl-2, which inhibit cell death when overexpressed (Bcl-xL Mcl-1, Bfl-1, Bcl-w and A1), and proapoptotic proteins which are sufficient to induce cell death when overexpressed (Bax, Bak, Bok, Bad, Bik/NBK, Bid and Hrk) (Kroemer, 1997; Rinkenberger and Korsmeyer, 1997). Viruses have also been shown to encode for proteins belonging to the Bcl-2 family (Rao and White, 1997).

The homologies between $\mathrm{Bcl}-2$ family members are clustered in discrete regions referred to as the $\mathrm{B} c l-2$ homology domains $(\mathrm{BH} 1-\mathrm{BH} 4)$. Bik, Bid and Hrk each contain a $\mathrm{BH} 3$ domain but no $\mathrm{BH} 1$ or $\mathrm{BH} 2$. The $\mathrm{BH} 4$ domain is only found in antiapoptotic proteins with the exception of an alternatively spliced form of $b c l-x$ called $\mathrm{Bcl}-\mathrm{xS}$, which may induce cell death. Some members of the $\mathrm{Bcl}-2$ family contain a carboxy terminal transmembrane domain, which may anchor these cytosolic proteins into intracellular membranes.

Bax was first characterised as the $\underline{B} c l-2$ associated protein $\underline{x}$, since it forms heterodimers with $\mathrm{Bcl}-2$ (Oltvai et al, 1993). Since then, homo- and heterodimer formation has been shown to be a common theme between almost all members of the Bcl-2 family (Farrow and Brown, 1996). For 
example, Bax may not only dimerise with $\mathrm{Bcl}-2$ but also with $\mathrm{Bcl}-\mathrm{xL}, \mathrm{Mcl}-1$ and $\mathrm{A} 1$, as well as with itself. $\mathrm{Bcl}-2$ and $\mathrm{Bcl}-\mathrm{xL}$ may in turn also form homodimers.

Interaction between $\mathrm{Bcl}-2$ family members are regulated at least in part, by the $\mathrm{BH} 1$ and $\mathrm{BH} 2$ domains (Yin et al, 1994). Mutations in these regions of Bcl-2 which disrupt its ability to form heterodimers with Bax correlate with a loss in its ability to inhibit cell death. $\mathrm{BH} 3$ binding domains of proapoptotic proteins like Bax, Bak, Hrk or Bik are necessary and sometimes sufficient for binding to $\mathrm{Bcl}-2$ or $\mathrm{Bcl}-\mathrm{xL}$ and for inducing cell death (Diaz et al, 1997; Han et al, 1996; Ink et al, 1997; Inohara et al, 1997). One interpretation of these results, has been put forward by Korsmeyer and collaborators who proposed a model in which $\mathrm{Bcl}-2$ or $\mathrm{Bcl}-\mathrm{xL}$ heterodimerises with Bax to suppress cell death (Merry and Korsmeyer, 1997). However mutations in $\mathrm{Bcl}-\mathrm{xL}$ have been described which disrupt heterodimerisation with Bax and Bak, but have only weak effects on the antiapoptotic activity of the protein (Cheng et al, 1996). This suggests that besides blocking proapoptotic proteins, $\mathrm{Bcl}-\mathrm{x}$ and perhaps $\mathrm{Bcl}-2$, may act independently to suppress cell death (Knudson and Korsmeyer, 1997).

\section{Molecular mechanisms by which $\mathrm{Bcl}-2$ related proteins may regulate cell death}

In most cases Bcl-2 family members have been shown to control the activation of caspases, a family of aspartate

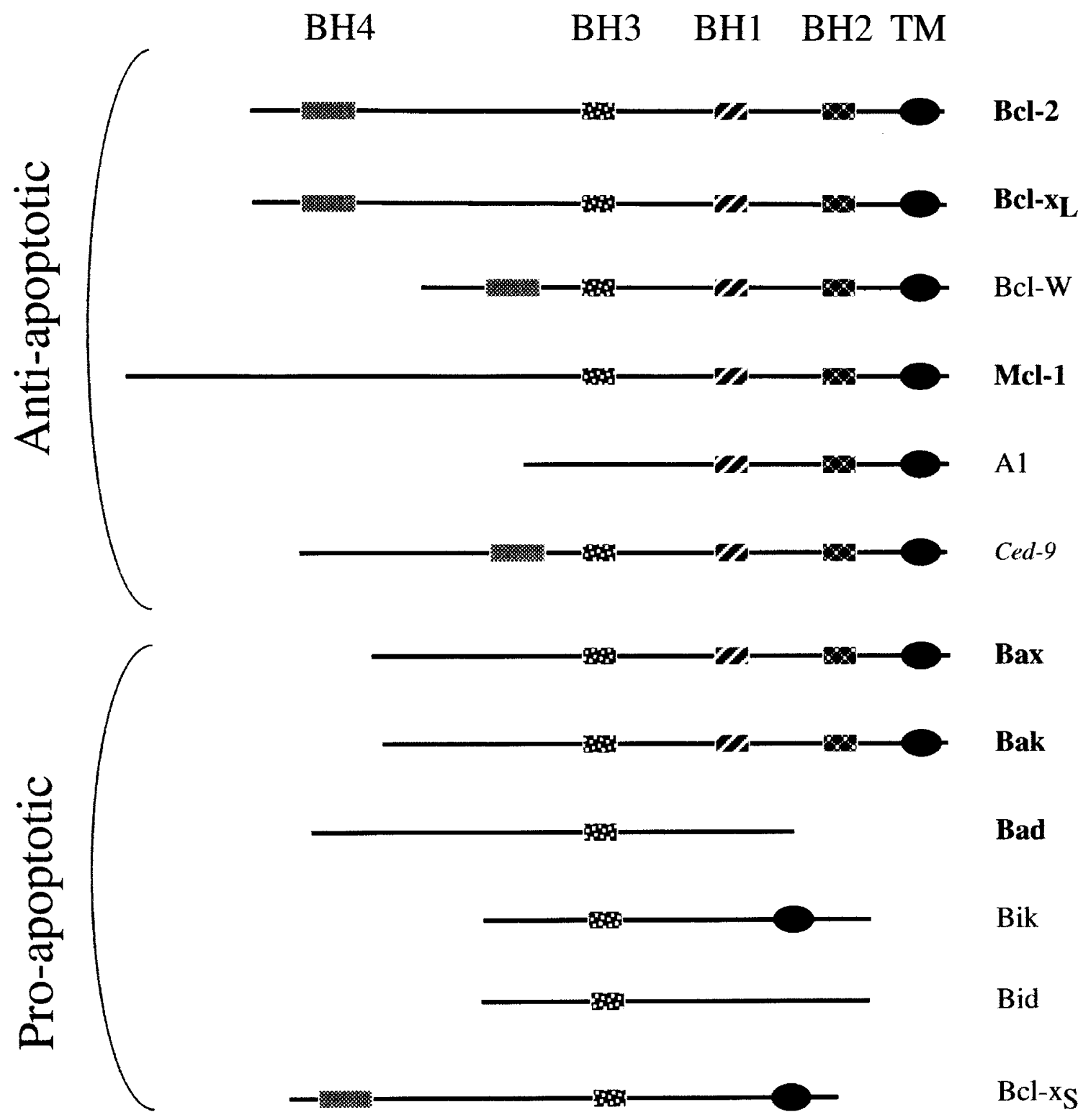

Figure $1 \mathrm{Bcl}-2$ family members. Only mamalian proteins are shown with the exception of Ced-9 which is a $C$. elegans protein. In bold are proteins with a proven expression in the nervous system. Viral proteins of the $\mathrm{Bcl}-2$ family have been omitted. $\mathrm{BH}$ domains are shown as $\mathrm{BH}$ - $\mathrm{BH} 4$. TM: putative transmembrane domain 
directed cysteine proteases central to the execution of programmed cell death (Salvesen et al, 1997; Frielander and Yuan, this volume). Several laboratories have shown that following a cell death stimulus, cytochrome $c$ is released from the mitochondria into the cytosol where it indirectly activates caspase 3/CPP32, a critical step in cells undergoing apoptosis (Figure 2A) (Kluck et al, 1997b; Zou et al, 1997). Antiapoptotic $\mathrm{Bcl}-2$ related proteins block the release of cytochrome $c$ into the cytosol, as shown from experiments using cells overexpressing $\mathrm{Bcl}-2$ or $\mathrm{Bcl}-\mathrm{xL}$ or purified mitochondria (Kluck et al, 1997a; Yang et al, 1997). On the other hand Bax can directly induce release of cytochrome $\mathrm{C}$ from isolated mitochondria (Jürgensmeier et al, 1998).

A link between cytochrome $c$ and caspase 3 activation has been recently described: cytochrome $\mathrm{c}$ binds an adaptor protein, Apaf-1, which in turn can bind to procaspase 9 . caspase 3 activation begins when caspase 9 binds Apaf- 1 in a reaction triggered by cytochrome $c$ and dATP. caspase 3 activation occurs through the cleavage of pro-caspase 3 by caspase 9 (Figure 2A). Interestingly, Apaf-1 shows significant sequence homologies to the $C$ elegans protein Ced-4 and to the terminal part of the caspase Ced-3 which are both required for cell death to occur in the worm (Zou et al, 1997).

The mechanism by which $\mathrm{Bcl}-2$ related proteins control the release of cytochrome $c$ into the cytosol may be related to their capacity to form channels in artificial membranes. It is the structural similarity between $\mathrm{Bcl}-\mathrm{xL}$ and the pore forming bacterial toxins diphtheria toxin and colicins (Muchmore et al, 1996) which has prompted several laboratories, including ourselves, to examine the capacity of Bcl-2 family members to form pores in membranes (Antonsson et al, 1997; Minn et al, 1997; Schendel et al, 1997; Schlesinger et al, 1997). Bcl-xL structure consists of two long hydrophobic $\alpha$ helices arranged in an anti-parallel fashion, surrounded by five amphipatic helices. $\mathrm{BH}-1, \mathrm{BH}-2$ and $\mathrm{BH}-3$ are in close proximity forming a hydrophobic cleft that may represent the binding site for other BCL-2 like proteins (Sattler et al, 1997).

The potential channel activities of $\mathrm{Bcl}-2$ family proteins were tested using recombinant soluble $\mathrm{Bax}, \mathrm{Bcl}-\mathrm{xL}$ and $\mathrm{Bcl}-$ 2, lacking their carboxy terminal transmembrane domain. Two groups (Schendel et al, 1997; Schlesinger et al, 1997) have demonstrated that $\mathrm{Bcl}-2$ can form discrete channels at $\mathrm{pH} 7$ with mild cation selectivity, a property reminiscent of that described by Minn et al (1997) for Bcl-xL. In contrast Bax exhibits an anionic selectivity. Noteworthy is the fact that the structure of the $\alpha 5$ and $\alpha 6$ helices which potentially form the channel varies among Bcl-2 family members, suggesting that these differences determine ion selectivity and/or conductance. The positively charged residues of Bax and negatively charged residues of $\mathrm{Bcl}-2$ may reflect their selectivities for anions and cations respectively.

The channel activities of both $\mathrm{Bcl}-\mathrm{xL}$ and $\mathrm{Bcl}-2$ are $\mathrm{pH}$ sensitive being greatly enhanced at $\mathrm{pH} 4$. In our hands, only Bax but not Bcl-2, was capable of forming detectable channels in lipid bilayers at physiological $\mathrm{pH}$. Consistent with all other studies, we found that both $\mathrm{Bax}$ and $\mathrm{Bcl}-2$ pore-forming activities as measured by $\underline{\text { Carboxyfluorescein }}$ (CF) efflux from liposomes, were greatly enhanced at lower
$\mathrm{pH}$ with Bax having a broader $\mathrm{pH}$ optimum. Using liposomes, we showed that at $\mathrm{pH} 7, \mathrm{Bcl}-2$ can antagonise Bax-induced leakage of the negatively charged CF (Antonsson et al, 1997).

Overexpressed Bax colocalises with $\mathrm{Bcl}-\mathrm{xL}$ and $\mathrm{Bcl}-2$ at the mitochondria, although $\mathrm{Bcl}-2$ is also detected in nuclear and reticular membranes (Rinkenberger and Korsmeyer, 1997). One may therefore hypothesize that following a death signal, Bax forms an anionic channel at the mitochondrial membrane leading to the opening of an unidentified pore through which cytochrome $c$ may be released (Jürgensmeier et al, 1998) (Figure 2A). One cannot exclude however, that Bax itself forms a pore large enough to allow cytochrome $c$ to flow through. Bax channel activity would also result in the loss of mitochondrial membrane potential which represents an early feature of apoptosis and occurs in cells overexpressing Bax (Xiang et al, 1996). Based on our results using liposomes, one may hypothesize that $\mathrm{Bcl}-2$ or $\mathrm{Bcl}-\mathrm{xL}$ inhibits cell death following the same death signal, by directly interacting with Bax and counteracting its channel activity and thereby inhibiting cytochrome c release and depolarisation (Figure 2Ba). Another hypothesis is that $\mathrm{Bcl}-2$ or $\mathrm{Bcl}-\mathrm{xL}$ form a cationic channel which allows to restore the ionic balance compromised by Bax (Figure 2Bb).

We now have evidence that classical channel blockers can mimic the effect of $\mathrm{Bcl}-2$ to block the release of $\mathrm{CF}$ from liposomes induced by Bax (D. Church and R. Sadoul unpublished observations). The final demonstration that Bax channel activity is essential to the cell death process, will await the demonstration that compounds which selectively block Bax channel activity can also block cell death. On the other hand, the development of $\mathrm{Bcl}-2$ channel agonists may also allow to mimic the effect of $\mathrm{Bcl}-2$ and thereby block active cell death.

Channel formation by $\mathrm{Bcl}-2$ family members is only one of the models which may account for their role in cell death. A number of interactions observed between $\mathrm{Bcl}-2$ family members and other proteins like ced 4, calcineurin, Raf-1, rRas, Bag-1 and p53-binding protein 2, which may also participate in cell death regulation, has led to numerous speculations regarding the role of $\mathrm{Bcl}-2$ like proteins in the control of cell death. These mechanisms have been extensively described in a number of recent reviews and will therefore not be developed herein (Kroemer, 1997; Reed, 1997; Rinkenberger and Korsmeyer, 1997).

\section{$\mathrm{Bcl}-2$ family proteins in the nervous system}

Until now, only Bcl-2, Bcl-xL, Mcl-1, Bax, Bak and Bad have been shown to be expressed by cells of the central and/or peripheral nervous system (Kitada et al, 1998; Krajewski et al, 1995a; Krajewski et al, 1996). Bcl-2 is widely expressed during nervous system development whereas in the adult, its expression is low in the central nervous system but stays high in the peripheral nervous system (Merry et al, 1994). In contrast $\mathrm{BCl}-\mathrm{xL}$ is highly expressed in both developing and adult nervous system (Frankowski et al, 1995; Gonzalez- 

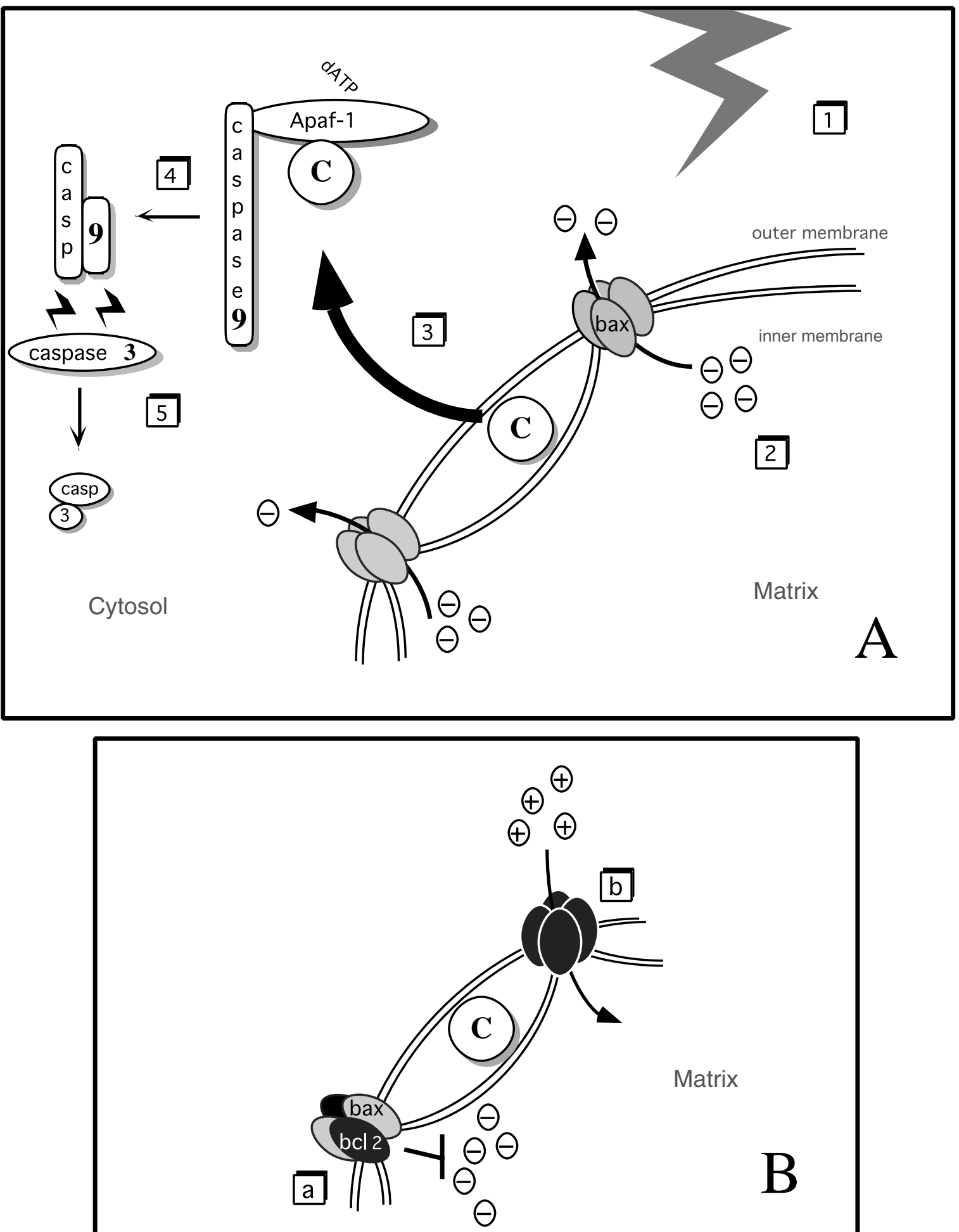

Matrix

B

Figure 2 Hypothetical model explaining how Bax and Bcl-2 may control cell death: (A) Following an apoptotic stimulus (1), mitochondrial Bax channels open to allow anion ( - ) efflux (2). This efflux results in a drop of mitochondrial membrane potential and release of cytochrome $c(C)$ into the cytosol (3). Cytochrome $c$ then interacts to Apaf-1, which together with dATP binds and activates procaspase 9 (4). Caspase 9 in turn activates procaspase 3 (5). (B) possible mechanisms explaining inhibition by Bcl-2 of Bax-induced cytochrome $\mathrm{c}$ leakage. (a) Bcl-2 associates with Bax to form a hybrid channel non permeable to anions (-) and thereby blocks anionic efflux. (b) Bcl-2 itself forms a channel allowing influx of cations (+) to counteract Bax induced anionic efflux 
Garcia et al, 1995). Bax is also highly expressed in the developing nervous system but its expression is strongly reduced after the period of naturally occurring cell death (Vekrellis et al, 1997).

\section{$\mathrm{Bcl}-2$ family proteins regulate neuronal apoptosis in vitro}

The demonstration that $\mathrm{Bcl}-2$ overexpression through microinjection of an expression vector into sympathetic neurons is able to protect from death induced by removal of nerve growth factor (NGF), provided the first indication that Bcl-2 family members play a central role in neuronal death and survival (Garcia et al, 1992). Using the same neurons, we demonstrated that $\mathrm{Bcl}-\mathrm{xL}$ overexpression also blocks NGFdeprivation-induced neuronal death (Martinou et al, 1995). Bcl-2 can also protect against neurotrophin deprivation in chick sympathetic neurons that depend on one or more neurotrophins (brain derived neurotrophic factor (BDNF), NGF, or neurotrophin-3 (NT-3)). In contrast, Bcl-2 does not rescue ciliary neurons from Ciliary Neurotrophic Factor (CNTF) deprivation, suggesting that $\mathrm{Bcl}-2$ dependent and independent cell death pathways may be used by neurons or that CNTF removal initiates the death program downstream of Bcl-2 (Allsopp et al, 1993).

Overexpression of Bax or Bak is sufficient to induce death of sympathetic neurons cultured in presence of NGF (Farrow et al, 1995; Martinou et al, 1998; Vekrellis et al, 1997). In this case, Bax-induced neuronal death can be blocked by inhibitors of caspases, which are also known to block neuronal death induced by NGF deprivation. These results suggest that neurotrophins regulate Bax activity which in turn controls the activation of caspases and thereby neuronal death. Regulation of $\mathrm{Bcl}-2$ like proteins by growth factors was recently demonstrated through Bad which controls the equilibrium between Bax and Bcl-2/BclXL (Datta et al, 1997; del Peso et al, 1997). Indeed Bad interacts with $\mathrm{Bcl}-2$ and $\mathrm{Bcl}-\mathrm{xL}$ and thereby inactivates their antiapoptotic properties (Yang et al, 1995). Upon phosphorylation Bad is sequestered by 14-3-3 proteins and is no longer available to interact with $\mathrm{Bcl}-2$ or $\mathrm{Bcl}-\mathrm{xL}$ which can counteract the proapoptotic effect of Bax. Bad has been demonstrated to be phosphorylated by AKT/PKB, a protein kinase controlled by growth factors such as IL-3, Insulin like growth factor (IGF-1) and NGF, through the activation of the phosphatidylinositide-3'-OH kinase. Thus, according to the current model, survival factors like NGF may promote cell survival by activating AKT phosphorylation of Bad, thereby allowing $\mathrm{Bcl}-2$ or $\mathrm{Bcl}-\mathrm{xL}$ to fulfil their antiapoptic function.

\section{Bcl-2 family proteins regulate neuronal survival during development}

During nervous system development, many neuronal cell populations including motoneurons, undergo a period of naturally occurring cell death (NOCD). The extent of neuronal death varies from region to region, but in most neuronal populations accounts for $25-70 \%$ of the initial number. The timing of NOCD occurs when neurons are receiving or making synapses, suggesting a relationship between neuronal death and the establishment of connectivity. The exact role of NOCD is still unclear, but may serve to match the number of neurons to the size of their target territory and to the number of their afferent projections. It may also allow the elimination of neurons having made aberrant connections. Neurotrophins may be involved in the mechanisms driving the selection of neurons since they are thought to be secreted in limiting amounts by the target cells. Selection would occur through competition for the survival factors.

In order to explore the role of Bcl-2 family members in regulating neuronal death in vivo, Martinou et al (1994) and Farlie et al, (1995) have generated transgenic mice containing $b c /-2$ under the control of the neurone specific enolase promoter which drives the protein's expression in neurons. In these mice, Bcl-2 expression begins before the onset of NOCD. Quantitative analysis of defined neuronal populations from the central and peripheral nervous system, demonstrated that $\mathrm{Bcl}-2$ overexpressing mice display $30-40 \%$ more neurons than wild animals. For example, a vast majority of the retinal ganglion cells found in the retina of neonatal $\mathrm{Bcl}-2$ overexpressors are maintained until adulthood, whereas only $40 \%$ survive in wild-type animals (Bonfanti et al, 1996). These findings demonstrate that during development some neurons use death pathways which can be blocked by $\mathrm{Bcl}-2$.

Bcl-2 overexpressing motoneurons of young animals are protected from axotomy of the facial- and sciatic nerve (Dubois-Dauphin et al, 1994; Farlie et al, 1995). Facial motoneurons overexpressing $\mathrm{Bcl}-2$ were shown to conserve functional electrophysiological properties similar to those of unlesioned motoneurons despite a reduction of the size of their soma (Alberi et al, 1996). Similarly, all ganglion cells of transgenic animals survive transection of the optic nerve, an axotomy which induces degeneration of $50 \%$ of ganglion cells in normal animals. In these experimental paradigms, the massive neuronal death following nerve section is only seen in very young animals around the time of NOCD, and can be rescued by neurotrophins (Lewin and Barde, 1996; Weibel et al, 1995).

The findings related to $\mathrm{Bcl}-2$ trangenic mice show that $\mathrm{Bcl}-2$ overexpression can protect neurons in situ from death induced by removal of trophic support and suggest that members of the $\mathrm{Bcl}-2$ family may control neuronal selection during development.

Studies of mice deficient for one or more proteins of the $\mathrm{Bcl}-2$ family made it possible to test their relative contribution during development. Deckwerth et al, (1996) have established that sympathetic neurons isolated from bax knock out $(-/-)$ mice are independent of NGF for their survival, a finding which correlates well with the protection of the same neurons by $\mathrm{Bcl}-2$ ectopic expression. As in the case of $\mathrm{Bcl}-2$ overexpressing mice, facial nuclei from bax $^{-1-}$ mice contain more neurons, which may correspond to neurons which have not undergone NOCD. Here again, motoneurons of the facial nucleus of $b^{-1-}$ mice are fully protected against axotomy, demonstrating that Bax is necessary for neuronal death after neurotrophic factor deprivation and during development. 
In contrast, $\mathrm{Bcl}-\mathrm{x}$ is required for cell survival early in development, since a massive apoptotic neuronal loss is observed in postmitotic neurons of the brain, spinal cord and dorsal root ganglia of homozygous mutant $b c /-x^{-1-}$ mouse embryos (Motoyama et al, 1995). In these mutants, cell death occurs in differentiated neurons prior to establishment of synaptic connections, and therefore is unlikely to represent an exacerbation of the targetdependent cell death described above.

Shindler et al (1997) demonstrated using mice deficient in both $b c l-x$ and bax $\left(b c l-x^{-/-} / b a x^{-1-}\right)$ that Bax deficiency can prevent the increased apoptosis of $b c /-x^{-1-}$ mutants. These results suggest that Bax acts as a dominant death effector protein which regulates cell death in the early developing nervous system, an activity tightly regulated through interactions with $\mathrm{Bcl}-\mathrm{xL}$. The remaining apoptosis observed in $\mathrm{bax}^{-1-}$ and $\mathrm{bax}^{-1-} / \mathrm{bcl-x^{-1- }}$ animals suggests a role for other members of the Bcl-2 family or for death pathways independent of the $\mathrm{Bcl}-2$ family in developmental neuronal death.

At birth, bcl-2 KO animals have the same number of facial motoneurons, sensory and sympathetic neurons as their wild-type counterparts (Michaelidis et al, 1996). Furthermore, axotomy-induced degeneration of facial motoneurons can still be prevented by BDNF or CNTF. However, a progressive degeneration of motor, sensory and sympathetic neurons from $b c /-2^{-1-}$ animals occurs after the period of NOCD. Therefore Bcl-2 does not appear to be a permissive factor for neurotrophic factors but seems crucial for the maintenance of survival in selective neurons.

The neuronal phenotypes observed in mice deficient in $b c l-2, b c /-x$ or bax are consistent with the hypothesis that the balance between pro- and antiapoptotic proteins of the $\mathrm{Bcl}-2$ family regulate the neuronal fate during development, even though the identity of those regulating neuronal selection stays unclear. They also suggest that the model put forward by Korsmeyer, which states that $\mathrm{Bcl}-2$ or $\mathrm{Bcl}-\mathrm{xL}$ suppress the death program by blocking Bax deleterious activity, is particularly relevant for neurons.

\section{Bcl-2 overexpression protects neurons from ischaemia}

The availability of the $\mathrm{Bcl}-2$ overexpressing mice has allowed to test whether such a balance between pro- and antiapoptotic proteins may also regulate neuronal survival following pathological insults in the adult brain. The first paradigm tested was the resistance to ischaemia following permanent occlusion of the middle cerebral artery, an experimental correlate of human stroke (Martinou et al, 1994). Bcl-2 efficiently protects neurons from ischaemic damage, since one week after the operation the estimated volume of the infarct was $40 \%$ less in $\mathrm{Bcl}-2$ overexpressors than in wild-type animals. Using herpes simplex virus (HSV) capable of overexpressing $\mathrm{Bcl}-2$ in intact brain, two groups have shown that $\mathrm{Bcl}-2$ protects neurons from ischaemia in the striatum and cortex (Lawrence et al, 1997; Linnik et al, 1995). Bcl-2 could still protect striatal neurons even when the HSV vector was delivered $1.5 \mathrm{~h}$ after focal ischaemia (Lawrence et al, 1997).
These data demonstrate the potential use of up regulating $\mathrm{Bcl}-2$ expression through gene therapy or of mimicking $\mathrm{Bcl}-2$ effect in order to limit the infarct damage following human stroke.

The mechanism by which $\mathrm{Bcl}-2$ overexpression may protect neurons from ischaemia is still unclear. Indeed neuronal death induced by ischaemia is due to both necrosis and apoptosis as demonstrated recently by several laboratories (Choi, 1996; Li et al, 1997). Necrosis appears to be mediated by hypoxia and over-activation of ionotropic glutamate receptors, especially $\mathrm{N}$-methyl-Daspartate receptors, with subsequent excessive $\mathrm{Ca}^{2+}$ influx. Bcl-2 overexpression protects cultured neurons against glutamate excitotoxicity (Jia et al, 1996; Lawrence et al, 1997) but cerebellar neurons isolated from $\mathrm{Bax}^{-1-}$ mice are not protected against glutamate (Miller et al, 1997) suggesting that, in this case, $\mathrm{Bcl}-2$ protective role is independent of Bax.

$A$ rapid and prolonged entry of calcium through glutamate receptors may lead to an increased $\mathrm{Ca}^{2+}$ load in the mitochondria. Up to a certain point this accumulation may be beneficial to the cell, since it decreases the intra-cytosolic concentration of $\mathrm{Ca}^{2+}$ which is a potent activator of several enzymes contributing to the active swelling and lysis typical of necrosis. However, in excess mitochondrial calcium can become deleterious since it induces an abrupt loss in mitochondrial polarisation and respiratory impairment (White and Reynolds, 1996; White and Reynolds, 1997). This impairment induces a number of harmful consequences such as ATP depletion, imbalance of ionic homeostasis or free radical generation which all drive necrotic cell damage (Nicotera et al, 1996). Murphy et al (1996) have shown that Bcl-2 potentiates the maximal uptake capacity of neural cell mitochondria and that this potentiation correlates with increased resistance of mitochondria to $\mathrm{Ca}^{2+}$ induced respiratory damage. $\mathrm{Bcl}-2$ expression also reduces $\mathrm{Ca}^{2+}$ efflux from the endoplasmic reticulum to the cytosol in thapsigargin treated cells (Lam et al, 1994) and modulates sustained increases in intranuclear $\mathrm{Ca}^{2+}$ (Marin et al, 1996). These effects of Bcl-2 on intracellular $\mathrm{Ca}^{2+}$ homeostasis may represent mechanisms by which the protein's overexpression protects neurons from the deleterious effect of $\mathrm{Ca}^{2+}$.

$\mathrm{Bcl}-2$ and $\mathrm{Bcl}-\mathrm{xL}$ have been shown to retard necrosis in non neuronal cells induced by oxygen depletion and respiratory chain inhibitors such as $\mathrm{KCN}$ and antimycin $\mathrm{A}$ (Shimizu et al, 1996). Loss of mitochondrial polarisation renders neurons more susceptible to low glutamate concentrations which induce typical signs of necrosis if the glutamate is applied together with cyanide $\mathrm{m}$ chlorophenyl hydrazone (CCP), an uncoupler of mitochondria (Nicotera et al, 1996). The capability of Bcl-2 to block the loss of mitochondrial membrane potential in compromised neurons may also serve to protect cells against mild calcium entry.

Beside necrosis, global and focal ischaemia also induce DNA fragmentation and morphological signs of apoptosis (Choi, 1996; Li et al, 1997). This ischaemic-apoptotic cell death may be a remote result of damage through necrosis, 
resulting from initiation of cytokine cascades, mild oxidative stress, synaptic or trophic deprivation induced by a loss of cellular or synaptic partners. It may also be a direct effect of mild glutamate toxicity, since Nicotera and colleagues have shown in neuronal cultures that short duration or low concentrations of glutamate may induce typical signs of apoptosis in some neurons (Ankarcrona et al, 1995; Bonfoco et al, 1995). Bax protein expression was shown to be induced after global ischaemia in neurons showing signs of apoptosis (Chen et al, 1996a; Krajewski et al, 1995b). One may therefore hypothesise that Bcl-2 overexpression blocks Bax activity and as a consequence ischaemic apoptosis. This model could be tested by comparing infarct size in bax $^{-1-}$ animals with that of $\mathrm{Bcl}-$ 2 overexpressors. This demonstration is particularly important in order to validate the therapeutical approach based on the development of Bax channel blockers to limit neuronal death in stroke.

Interestingly $\mathrm{Bcl}-\mathrm{xL}$ and $\mathrm{Bcl}-2$ protein expression is upregulated in neurons in regions of the hippocampus which are the least affected by degeneration following global ischaemia suggesting, a role of antiapoptotic genes as inducible neuroprotective agents (Chen et al, 1997; Krajewski et al, 1995b).

\section{A potential role for blocking neuronal death by mimicking Bcl-2 function to treat other acute pathologies of the nervous system}

Beside ischaemia, overexpression of $\mathrm{Bcl}-2$ in normal photoreceptors was also shown to decrease the damaging effects of constant light exposure (Chen et al, 1996b). Other types of experimental acute stresses can reproduce pathologies of the nervous system observed in human. None of these stresses have yet been tested in mice which overexpress $\mathrm{Bcl}-2$, but the detection of typical apoptotic cells in several regions affected by these pathologies suggests that blocking apoptosis through $\mathrm{Bcl}-2$ could be a way to limit neuronal damage.

Typical features of apoptosis have been detected in the hippocampus of animals injected with kainate, an activator of non NMDA receptors. This model is often used as a correlate to status epilepticus in humans and suggests that in vivo, active cell death may be a consequence of epileptic seizures. Bcl-2 protein expression is upregulated only in the CA1 region of the hippocampus which contains neurons surviving the kainate induced seizures. (Graham et al, 1996). This contrasts the Bcl-2 protein upregulation following global ischaemia, which occurs only in neurons from the dentate and CA3 regions of the hippocampus which are most resistant to this type of ischaemia (Chen et al, 1997; Krajewski et al, 1995b). Interestingly bcl-2 mRNA expression is upregulated in both CA1 and CA3 following kainate injection or global ischaemia suggesting, a role for translational blockage or for protein degradation in the regulation of $\mathrm{Bcl}-2$ protein expression.

Neuronal death which occurs after experimental brain injury in the rat has features of both apoptosis and necrosis (Rink et al, 1995). In this system apoptosis may account for the delayed neuronal death which occurs up to $72 \mathrm{~h}$ following the trauma. $b c /-2$ mRNA and protein expression is also upregulated following traumatic brain injury in the rat in the peritrauma cortex and hippocampus. Here again, neurons which express $\mathrm{Bcl}-2$ survive preferentially following the trauma (Clark et al, 1997).

Recently, two independent groups have carefully described the death features of cells dying after spinal cord injury (Crowe et al, 1997; Liu et al, 1997). Typical signs of necrosis occur following spinal cord contusion in rats and monkeys. Apoptotic neurons and glial cells were also detected from $6 \mathrm{~h}$ to 3 weeks following injury. Apoptotic cells were observed adjacent to myelin sheets and were demonstrated to be oligodendrocytes. This apoptotic death of oligodendrocytes may be a result of the degeneration of the fibre tracts following the injury. Therefore both secondary degeneration at the site of $\mathrm{SCl}$ and the chronic demyelination of tracts away from the injury may be due in part to apoptosis. The long time course of the secondary injury processes suggests that intervention for blocking programmed cell death may be of great value in limiting the damage to neurons and myelin forming cells. This last example of secondary apoptosis following trauma in the central nervous system shows that delayed cell death is not restricted to neurons but affects also glial cells which play a vital role in maintaining a fully functional nervous system.

\section{A role for $\mathrm{Bcl}-2$ family proteins in chronic neurodegeneration??}

Up till now it has been difficult to ascertain a role for $\mathrm{Bcl}-2$ like proteins in slowly-progressing neurodegenerative diseases which are characterised by a degeneration of specific populations of neurons. However, a beneficial role of antiapoptotic $\mathrm{Bcl}-2$ members in these pathologies may be suggested in view of the increasing evidence showing that defects in mitochondrial energy production and in $\mathrm{Ca}^{2+}$ buffering may underlie neuronal death in Alzheimer's disease (AD), Parkinson's disease (PD) and amyotrophic lateral sclerosis (ALS) (Beal, 1996).

\section{Parkinson's and Alzheimer's diseases}

Several studies have shown that PD is associated with reduced mitochondrial complex I activity in platelets, muscle and substantia nigra. Mitochondria from PD patients have been transferred into rho $^{\circ}$ recipient neuroblastoma cells (mitochondrial-DNA-free) to create cybrids. These PD cybrids were shown to have increased oxygen radical production and susceptibility to 1-methyl-4-phenyl pyridinium-induced programmed cell death (MPP+) (Sheehan et al, 1997b; Swerdlow et al, 1996). MPP+ is the reactive metabolite of 1-methyl-4-phenyl-1,2,3,6-tetrahydropyridine (MPTP) which produces a syndrome, both in man and in animals, that closely mimics idiopathic PD. This involves production of MPP+ which is taken up by dopaminergic neurons, inhibition of the mitochondrial complex I, and free radical generation which contributes to the destruction of the dopaminergic neurons. Dopaminergic neurons from trans- 
genic mice overexpressing $\mathrm{Bcl}-2$ are protected from MPTP toxicity (Offen et al, 1998). Hockenbery et al (1993) have shown that $\mathrm{Bcl}-2$ protects cells by an unknown mechanism, from damaging effects of reactive oxygen species such as lipid peroxydation. Therefore, Bcl-2 protection against MPP+ cytotoxicity may be in part related to its antioxidant properties.

Mitochondria from $A D$ have also been used to create $A D$ cybrids. Here as well, these AD cybrids display an increase in free radical production. Both $A D$ - and PD-cybrids show impairment of $\mathrm{Ca}^{2+}$ buffering as revealed by a slower recovery from elevation in cytosolic calcium induced by the inositol-1,4,5-triphosphate (InsP3) agonist carbachol (Sheehan et al, 1997a,b) compared to control cybrids. Since the mitochondria is today recognised as one of the major regulator of cytosolic $\mathrm{Ca}^{2+}$, one may hypothesize that $P D$ and $A D$ mitochondria are impaired in their $\mathrm{Ca}^{2+}$ buffering function. Alterations in calcium homeostasis and ROS generation might lead to increased susceptibility to cell death under circumstances not ordinarily toxic. In view of the increased maximum uptake capacity of mitochondria conferred by Bcl-2 (Murphy et al, 1996), it will be interesting to test whether overexpression of $\mathrm{Bcl}-2$ in $\mathrm{PD}$ or $\mathrm{AD}$ cybrids is capable of restoring normal calcium homeostasis.

Interestingly, $\beta$ Amyloid which is the major component of amyloid plaques seen in AD brains, may have a direct role on the $\mathrm{Bax} / \mathrm{Bcl}-2$ equilibrium inside the cell. Indeed $\beta$ Amyloid incubated with cultured human neurons down regulates $\mathrm{Bcl}-2$ and upregulates Bax-expression by these neurons (Paradis et al, 1996). This peptide is a hallmark of $A D$ but the question of its direct toxicity remains controversial. The findings of Paradis may suggest a mechanism by which accumulation of $\beta$ Amyloid may render neurons more vulnerable to age-dependent stress and thereby contribute to the disease.

\section{Motoneuron diseases}

The observation that mutations in $\mathrm{Cu} / \mathrm{Zn}$ superoxide dismutase 1 (SOD1) accounts for $20 \%$ of the inherited forms of ALS suggested that a perturbation in free radical homeostasis might play a role in the development of the disease (Rosen et al, 1993). Overexpression of SOD1 mutations associated with ALS in transgenic mice causes motoneuron degeneration resembling that seen in this human pathology, despite normal or increased SOD1 activity (Ripps et al, 1995; Wong et al, 1995). Recently, Kostic and colleagues have reported the effect of neuronal Bcl-2 overexpression on this pathology by crossing SOD1 transgenic animals with $\mathrm{Bcl}-2$ overexpressors (Kostic et al, 1997). The overexpression of human Bcl-2 delayed the onset of the disease by $19 \%$, but had no effect on the duration of the pathology. Interestingly, overexpression of Bcl-2 attenuated the motor neuronal loss seen in the SOD1 ovexpressor suggesting that neuronal death does not account for all clinical signs of the disease. In these SOD1/Bcl-2 overexpressors one potential site of Bcl-2 activity may be the mitochondria which are affected in ALS: an early abnormality in the transgenic ALS mice is a mitochondrial swelling (Wong et al, 1995). Also, studies of muscle biopsies of ALS patients have shown that nerve terminals have significant increases in calcium (Siklos et al, 1996). This suggests a use for $\mathrm{Bcl}-2$ overexpression as a therapeutical tool to protect mitochondria from damage induced by calcium overloads as discussed above.

Three candidate genes have been implicated in spinal muscular atrophy (SMA), another motoneuron disease which affects the anterior horn cells of the spinal cord. From these three genes, two may encode proteins directly controlling the cell death programme: the neuronal-antiapoptosis protein (NAIP) and the spinal motor neuron protein (SMN).

NAIP gene encodes a protein which belongs to a family of viral and cellular proteins called IAP (inhibitor of apoptosis) most of which have anti-death activities (Clem and Ducket, 1997). IAP proteins may block apoptosis through different mechanisms since some are central components of the TNF receptor pathway, others bind to the drosophila Reaper while others inhibit directly caspases (Clem and Ducket, 1997; Devereaux et al, 1997; Vucic et al, 1997). NAIP overexpression has been shown to inhibit apoptosis induced by a variety of signals through an unknown mechanism (Liston et al, 1996).

The SMN gene is deleted or interrupted in almost all SMA patients. Mice with homozygous SMN disruption display massive cell death during early embryonic development, indicating that the SMN gene product is necessary for cellular survival and function (Schrank et al, 1997). Recently, Tsujimoto and colleagues have demonstrated that SMN can directly interact with Bcl-2. Furthermore, they showed that although SMN had only weak antiapoptotic activity, coexpression of SMN with Bcl-2 confers a synergistic preventive effect against Bax induced or Fas-mediated toxicity. However, SMN carrying a missense mutation found in one SMA patient had no synergistic effect with Bcl-2 (Iwahashi et al, 1997). These results are important since they are the first to indicate that genetic defects in regulation of Bcl-2 family members could underlie some type of neurodegenerative diseases.

\section{Conclusion}

The demonstration that neuronal death can be blocked by manipulation of the cell death program, regardless of the cell death signal, has raised enormous hopes for the treatment of neurodegenerative diseases in which the cell death signals are of unknown origin or have already occurred. These hopes have been reinforced with the recent findings that Bcl-2 family members may form channels in intracellular membranes, since it is now possible that pharmacological modulation of these channels may give new opportunities to block cell death. Furthermore this approach may also turn out to be usefull in helping regeneration of injured neurons as $\mathrm{Bcl}-2$ was recently found to play a role in regulating neurite outgrowth (see Chen and Tonegawa, this volume). Bax is well suited for this type of manipulation since blocking its channel activity is likely to be a readily achievable goal. Bax blocking compounds will allow to test if Bax channel activity is an early and central step in neuronal apoptosis. If this is the case, these compounds may prove to be powerful drugs to block the neuronal loss characteristic of neurodegenerative diseases. However, the potential use of antiapoptotic drugs mimicking 
$\mathrm{Bcl}-2$ for treating chronic neurodegenerative diseases could be hampered by their possible side effects which may be foreseen when given over long periods of time. Indeed prolonged use of general suppressors of apoptosis may lead to hyperplasia and possibly contribute to tumour formation in other cell types and trigger uncontrolled inflammatory responses. In contrast, antiapoptotic drugs given over a short period of time may be of tremendous interest to treat acute pathologies of the central nervous system. These pathologies involve apoptosis especially during delayed cell death which participates in the damage due to ischaemia, brain and spinal cord injury and perhaps epileptic seizures. Here the timing of delayed death should give a reasonable time frame for the treatment of these pathologies with cell death blockers. Nevertheless it should be kept in mind that neuronal death in the pathological brain may be the end result of a process involving loss of connections, impaired axonal transport or impaired metabolism. Therefore, even though they raise enormous hopes, the success of antiapoptotic therapies will depend on the ability of neurons not only to survive but also to recover from these different types of damages. At least we may soon have the opportunity to give neurons a chance to do so!

\section{Acknowledgements}

Many thanks to all my colleagues for discussions and ideas, and more specifically to K. Maundrell, Isabelle De Bie, K. Sadoul and J.C. Martinou for critical reading of the manuscript.

\section{References}

Alberi S, Raggenbass M, Debilbao F and Dubois-Dauphin M (1996) Axotomized neonatal motoneurons overexpressing the $\mathrm{Bcl} 2$ proto-oncogene retain functional electrophysiological properties. Proc. Natl. Acad. Sci. USA. 93: 3978-3983

Allsopp TE, Wyatt S, Paterson HF and Davies AM (1993) The proto-oncogene bcl-2 can selectively rescue neurotrophic factor-dependent neurons from apoptosis. Cell 73: 295-307

Ankarcrona M, Dypbukt JM, Bonfoco E, Zhivotovsky B, Orrenius S, Lipton SA and Nicotera $P$ (1995) Glutamate-induced neuronal death: a succession of necrosis or apoptosis depending on mitochondrial function. Neuron. 15: 961-973

Antonsson B, Conti F, Ciavatta A, Montessuit S, Lewis S, Martinou I, Bernasconi L, Bernard A, Mermod JJ, Mazzei G, Maundrell K, Gambale F, Sadoul R and Martinou JC (1997) Inhibition of Bax channel-forming activity by Bcl-2. Science 277: $370-372$

Beal MF (1996) Mitochondria, free radicals, and neurodegeneration. Cur. Op. Neurobio. 6: 661-666

Bonfanti L, Strettoi E, Chierzi S, Cenni M, LiuX, Martinou J-C, Maffei Land RabacchiS (1996) Protection of retinal ganglion cells from natural and axotomy-induced cell death in neonatal transgenic mice overexpressing bcl-2. J. Neurosci. 16: $4186-$ 4194

Bonfoco E, Krainc D, Ankarcrona M, Nicotera P and Lipton SA (1995) Apoptosis and necrosis: two distinct events induced, respectively, by mild and intense insults with $\mathrm{N}$-methyl-D-aspartate or nitric oxide/superoxide in cortical cell cultures. Proc. Natl. Acad. Sci. USA 92: 7162-7166

Chen J, Zhu RL, Nakayama M, KawaguchiK, Jin KL, Stetler A, Simon RP and Graham $\mathrm{SH}$ (1996a) Expression of the apoptosis-effector gene, Bax, is up-regulated in vulnerable hippocampal Ca1 neurons following global ischemia. J. Neurochem. 67: $64-71$

Chen J, Flannery J, LaVail M, Steinberg R, Xu J and Simon M (1996b) bcl-2 overexpression reduces apoptotic photoreceptor cell death in three different retinal degenerations. Proc. Natl. Acad. Sci. USA. 93: 7042-7047
Chen J, Graham SH, Nakayama M, Zhu RL, Jin K, Stetler RA and Simon RP (1997) Apoptosis repressor genes $\mathrm{Bcl}-2$ and $\mathrm{Bcl}-\mathrm{x}$-long are expressed in the rat brain following global ischemia. J. Cereb. Blood Flow Metab. 17: 2-10

Cheng EHY, Levine B, Boise LH, Thompson CB and Hardwick JM (1996) Baxindependent inhibition of apoptosis by $\mathrm{Bcl}-\mathrm{X}(\mathrm{L})$. Nature 379: $554-556$

Choi DW (1996) Ischemia-induced neuronal apoptosis. Cur.Op. Neurobiol. 6: $667-$ 672

Clark RS, Chen J, Watkins SC, Kochanek PM, Chen M, Stetler RA, Loeffert JE and Graham SH (1997) Apoptosis-suppressor gene bcl-2 expression after traumatic brain injury in rats. J Neurosci. 17: 9172-9182

Clem RJ and Ducket CS (1997) The iap genes: unique arbitrators of cell death. Trends. Cell Biol. 7: $337-339$

Crowe MJ, Bresnahan JC, Shuman SL, Masters JN and Beattie MS (1997) Apoptosis and delayed degeneration after spinal cord injury in rats and monkeys. Nature Med. 3: $73-76$

Datta SR, Dudek H, Tao X, Masters S, Fu H, Gotoh Y and Greenberg ME (1997) AKT Phosphorylation of BAD couples survival signals to the cell-intrinsic death machinery. Cell. 91: 231-241

Deckwerth TL, Elliott JL, Knudson CM, Johnson EM, Snider WD and Korsmeyer SJ (1996) Bax is required for neuronal death after trophic factor deprivation and during development. Neuron. 17: 401-411

del Peso L, Gonzalez-Garcia M, Page C, Herrera Rand Nunez G (1997) Interleukin-3 induced phophorylation of Bad through the protein kinase AKT. Science 278: $687-689$

Devereaux QL, Takahashi R, Salvesen GS and Reed JC (1997) X-linked IAP is a direct inhibitor of cell-death proteases. Nature 388: 300-304

Diaz JL, Oltersdorf T, Horne W, McConnell M, Wilson G, Weeks S, Garcia T and Fritz LC (1997) A common binding site mediates heterodimerization and homodimerization of Bcl-2 family members. J. Biol. Chem. 272: 1135011355

Dubois-Dauphin M, Frankowski Y, Tsujimoto J, Huarte J and Martinou JC (1994) Neonatal motoneurons overexpressing the bcl-2 protooncogene in transgenic mice are protected from axotomy-induced cell death. Proc. Natl. Acad. Sci. USA. 91: $3309-3313$

Farlie PG, Dringen R, Rees SM, Kannourakis G and Bernard O (1995) bcl-2 transgene expression can protect neurons against developmental and induced cell death. Proc. Natl. Acad. Sci. USA. 92: 4397-4401

Farrow SN and Brown R (1996) New members of the Bcl-2 family and their protein partners. Cur. Op. Gen. Dev. 6: 45-49

Farrow SN, White JH, Martinou I, Raven T, Pun KT, Grinham CJ, Martinou CJ and Brown R (1995) Cloning of a bcl-2 homologue by interaction with adenovirus E1B 19K. Nature 374: $731-733$

Frankowski H, Missotten M, Fernandez PA, Martinou I, Michel P, Sadoul R and Martinou JC. (1995). Function and expression of the bcl-X Gene in the developing and adult nervous system. Neuroreport. 6: 1917-1921

Garcia I, Martinou I, Tsujimoto Y and Martinou JC (1992) Prevention of programmed cell death of sympathetic neurons by the bcl-2 proto-oncogene. Science 258 : $302-304$

Gonzalez-Garcia M, Garcia I, Ding L, O'Shea S, Boise LH, Thompson CB and Nunez $\mathrm{G}$ (1995) bcl-x is expressed in embryonic and postnatal neural tissues and functions to prevent neuronal cell death. Proc. Natl. Acad. Sci. USA. 92: 43044308

Graham SH, Chen J, Stetler RA, Zhu RL, Jin KL and RP Simon (1996) Expression of the proto-oncogene $\mathrm{Bcl}-2$ is increased in the rat brain following kainate-induced seizures. Restorative Neurol. Neurosci. 9: 243

Hamburger V and Oppenheim RW (1982) Naturally occuring death in vertebrates. Neurosci. Comment. 1: 39-55

Han J, Sabbatini P and White E (1996) Induction of apoptosis by human Nbk Bik, a $\mathrm{BH} 3$-containing protein that interacts with E1b 19k. Mol. Cell. Biol. 16: 58575864

Hockenbery D, Nunez G, Milliman C, Schreiber RD and Korsmeyer SJ (1990) Bcl-2 is an inner mitochondrial membrane protein that blocks programmed cell death. Nature 348: $334-336$

Hockenbery DM, Oltvai ZN, Yin XM, Milliman CL and Korsmeyer SJ (1993) Bcl-2 functions in an antioxidant pathway to prevent apoptosis. Cell 75: 241-251

Ink B, Zornig M, Baum B, Hajibagheri N, James C, Chittenden T and Evan G (1997) Human Bak induces cell death in Schizosaccharomyces Pombe with Morphological changes similar to those with apoptosis in mammalian cells. Mol. Cell. Biol. 17: 2468-2474 
Inohara N, Ding LY, Chen S and Nunez G (1997) Harakiri, a novel regulator of cell death, encodes a protein that activates apoptosis and interacts selectively with survival-promoting proteins Bcl-2 and Bcl-X-L. EMBO J. 16: 1686- 1694

Iwahashi $\mathrm{H}$, Eguchi $\mathrm{Y}$, Yasuhara N, Hanafusa $\mathrm{T}$, Matsuzawa $\mathrm{Y}$ and Tsujimoto $\mathrm{Y}$ (1997) Synergistic anti-apoptotic activity between Bcl-2 and SMN implicated in spinal muscular atrophy. Nature 390: 413-417

Jia WW, Wang Y, Qiang D, Tufaro F, Remington R and Cynader M. (1996) A bcl-2 expressing viral vector protects cortical neurons from excitotoxicity even when administered several hours after the toxic. Mol. Brain Res. 42: 350-353

Jürgensmeier JM, Xie Z, Deveraux Q, Ellerby L, Bredesen D and Reed JC (1998) Bax directly induces release of cytochrome $c$ from isolated mitochondria. Proc. Natl. Acad. Sci. USA. 95: 4997-5002

Kitada S, Krajewska M, Zhang X, Scudiero D Zapata JM, Wang HG, ShabaikA, Tudor G, Krajewski S, Myers TG, Johnson GS, Sausville EA and Reed JC (1998) Expression and location of pro-apoptotic Bcl-2 family protein BAD in norma human tissues and tumor cell lines. Am. J. Pathol. 152: 51-61

Kluck RM, Bossywetzel E, Green DR and Newmeyer DD (1997a) The release of cytochrome c from mitochondria - a primary site for $\mathrm{Bcl}-2$ regulation of apoptosis. Science 275: $1132-1136$

Kluck RM, Martin SJ, Hoffman BM, Zhou JS, Green DR and Newmeyer DD (1997b) Cytochrome c Activation of cpp32-like proteolysis plays a critical role in a Xenopus cell-free apoptosis system. EMBO J. 16: 4639-4649

Knudson CM and Korsmeyer SJ (1997) Bcl-2 and Bax function independently to regulate cell death. Nature Genet. 16: 358-363

Kostic V, Jackson-Lewis V, de Bilbao F, Dubois-Dauphin M and Przedborski S (1997) Bcl-2: prolonging life in a transgenic mouse model of familial amyotrophic lateral sclerosis. Science 275: 559-562

Krajewski S, Bodrug S, Krajewska M, ShabaikA, Gascoyne R, Berean KandReed JC (1995a) Immunohistochemical analysis of Mcl-1 protein in human tissues. Differential regulation of $\mathrm{Mcl}-1$ and $\mathrm{Bcl}-2$ protein production suggests a unique role for Mcl-1 in control of programmed cell death in vivo. Am J Pathol. 146: $1309-1319$

KrajewskiS, MaiK, Krajewska M, Sikorska M, Mossakowski MJ and ReedJC (1995b) Upregulation of bax protein levels in neurons following cerebral ischemia. J. Neurosci. 15: 6364-6376

Krajewski S, Krajewska M and Reed JC (1996) Immunohistochemical analysis of in vivo patterns of Bak expression, a proapoptotic member of the $\mathrm{Bcl}-2$ protein Ffamily. Cancer Res. 56: 2849-2855

Kroemer G (1997) The proto-oncogene Bcl-2 and its role in regulating apoptosis. Nature Med. 3: 614-620

Lam M, Dubyak G, Chen L, Nunez G, Miesfeld RL and Distelhorst CW (1994) Evidence that $B C L-2$ represses apoptosis by regulating endoplasmic reticulumassociated Ca2+ fluxes. Proc. Natl. Acad. Sci. USA. 91: 6569-6573

Lawrence MS, McLaughlin JR, Sun GH, Ho L, McIntosh L, Kunis DM, Sapolsky RM and Steinberg GK (1997) Herpes Simplex viral vectors expressing Bcl-2 are neuroprotective when delivered after a stroke. J. Cereb. Blood Flow.Metab. 17: $740-744$

Lewin G R and Barde YA (1996) Physiology of the neurotrophins. An. Rev. Neurosci. 19: $289-317$

Li Y, Chopp M, Powers C and Jiang M (1997) Apoptosis and protein expression after focal cerebral ischemia in rat. Brain Res. 765: 301-312

Linnik MD, Zahos P, Geschwind MD and Federoff HJ (1995) Expression of bcl-2 from a defective herpes simplex virus-1 vector limits neuronal death in focal cerebra ischemia. Stroke 26: 1670-1674

Liston P, Roy M, Tamai K, Lefebvre C, Baird S, Cherton-Horvat G, Farahani R, McLean M, Ikeda JE, MacKenzie A and Korneluk RG (1996) Suppression of apoptosis in mammalian cells by NAIP and a related family of IAP genes. Nature 379: $349-353$

Liu XZ, Xu XM, Hu R, Du C, Zhang SX, McDonald JW, Dong HX, Wu YJ, Fan GS, Jacquin MF, Hsu CY and Choi DW (1997) Neuronal and glial apoptosis after traumatic spinal cord injury. J. Neurosci. 17: 5395-5406

Marin MC, Fernandez A, Bick RJ, Brisbay S, Buja LM, Snuggs M, McConkey DJ, von Eschenbach AC, Keating MJ and McDonnell TJ (1996) Apoptosis suppression by bcl-2 is correlated with the regulation of nuclear and cytosolic $\mathrm{Ca} 2+$. Oncogene 12: 2259-2266

Martinou I, Fernandez P, Missotten M, White E, Sadoul R, and Martinou JC (1995) Viral proteins E1B19K and p35 protect sympathetic neurons from cell death induced by NGF deprivation. J Cell Biol. 128: 201-208
Martinou I, Missotten M, Fernandez P, Sadoul R and Martinou J (1998) Bax and Bak proteins require caspase activity to trigger apoptosis in sympathetic neurons. Neuroreport 9: 15-19

Martinou JC, Dubois-Dauphin M, Staple JK, Rodriguez I, Frankowski H, Missotten M, Albertini P, Talabot D, Catsicas S, Pietra C and Huarte J (1994) Overexpression of $\mathrm{Bcl}-2$ in transgenic mice protects neurons from naturally occurring cell death and experimental ischemia. Neuron. 13: 1017-1030

Merry DE and Korsmeyer SJ (1997) Bcl-2 Gene family in the nervous system. Ann. Rev. Neurosci. 20: 245-267

Merry DE, Veis DJ, Hickey WF and Korsmeyer SJ (1994) Bcl-2 protein expression is widespread in the developing nervous system and retained in the adult PNS. Development 120: 301-311

Michaelidis TM, Sendtner M, Cooper JD, Airaksinen MS, Holtmann B, Meyer M and Thoenen $\mathrm{H}$ (1996). Inactivation of bcl-2 results in progressive degeneration of motoneurons, sympathetic and sensory neurons during early postnatal development. Neuron. 17: 75-89

Miller TM, Moulder KL, Knudson CM, Creedon DJ, Deshmukh M, Korsmeyer SJ and Johnson EM (1997) Bax deletion further orders the cell death pathway in cerebellar granule cells and suggests a caspase-independent pathway to cell death. J. Cell Biol. 139: 205-217

Minn AJ, Velez P, Schendel SL, Liang H, Muchmore SW, Fesik SW, Fill M and Thompson CB (1997) Bcl-x(L) forms an ion channel in synthetic lipid membranes. Nature 385: 353-357

Motoyama N, Wang F, Roth A, Sawa H, Nakayama K, Nakayama K, Negishi I, Senju S, Zhang Q, Fujii S and Loh DY (1995) Massive cell death of immature hematopoietic cells and neurons in Bcl-x-deficient mice. Science. 267: 15061510

Muchmore SW, M. Sattler M, Liang H, Meadows RP, Harlan JE, Yoon HS, Nettesheim D, Chang BS, Thompson CB, Wong SL, Ng SL and Fesik SW (1996) X-ray and NMR structure of human $\mathrm{Bcl}-\mathrm{xL}$, an inhibitor of programmed cell death. Nature 381: $335-341$

Murphy AN, Bredesen DE, Cortopassi G, Wang E and Fiskum G (1996) Bcl-2 potentiates the maximal calcium uptake capacity of neural cell mitochondria. Proc. Natl. Acad. Sci. USA. 93: 9893-9898

Nicotera P, Ankarcrona M, Bonfoco E, Orrenius S and Lipton SA (1996) Neuronal apoptosis versus necrosis induced by glutamate or free radicals. Apoptosis 1:510

Offen D, Beart PM, Cheung NS, Pascoe CJ, Hochman A, Gorodin S, Melamed E, Bernard R and Bernard O (1998) Transgenic mice expressing human bcl-2 in their neurons are resistant to 6-hydroxydopamine and 1-methyl-4-phenyl1,2,3,6- tetrahydropyridine neurotoxicity. Proc. Natl. Acad. Sci. USA. 12:57895794

Oltvai ZN, Milliman CL and Korsmeyer SJ (1993) Bcl-2 heterodimerizes in vivo with a conserved homolog, Bax, that accelerates programmed cell death. Cell 74: $609-619$

Oppenheim RW (1991) Cell death during development of the nervous system. Ann. Rev. Neurosci. 14: 453-501

Paradis E, Douillard H, Koutroumanis M and Goodyer C (1996) Amyloid beta peptide of Alzheimer's disease downregulates $\mathrm{Bcl}-2$ and upregulates Bax expression in human. J. Neurosci. 16: 7533-7539

Raff MC, Barres BA, Burne JF, Coles HS, Ishizaki Y and Jacobson MD (1993) Programmed cell death and the control of cell survival: lessons from the nervous system. Science 262: $695-700$

Rao $L$ and White $E$ (1997) Bcl-2 and the Ice family of apoptotic regulators - making a connection. Cur. Op. Gen. Dev. 7: 52-58

Reed JC (1997) Double identity for proteins of the Bcl-2 family. Nature 387: 773-776

Rink A, Fung KM, Trojanowski JQ, Lee VM, Neugebauer E and McIntosh TK (1995) Evidence of apoptotic cell death after experimental traumatic brain injury in the rat. Am. J. Pathol. 147: 1575-1583

Rinkenberger JL and Korsmeyer SJ (1997) Errors of homeostaasis and deregulated apoptosis. Cur. Op. Gen. Dev. 7: 589-596

Ripps ME, Huntley GW, Hof PR, Morrison JH, and Gordon JW (1995) Transgenic mice expressing an altered murine superoxide dismutase gene provide an animal model of amyotrophic lateral sclerosis. Proc. Natl. Acad. Sci. USA. 92: $689-693$

Rosen DR, Siddique T, Patterson D, Figlewicz D, Sapp P, Hentati A, Donaldson D, Goto J, O'Regan J, Deng H, et al. (1993) Mutations in Cu/Zn superoxide dismutase gene are associated with familial amyotrophic sclerosis. Nature 362 : $59-62$ 
Sadoul R, Catsicas S and Martinou JC (1994) Neuronal death: common mechanisms during development and disease. Sem. Neurosci. 6: 343-346

Salvesen GS and DixitV (1997) Caspases : Intracellular signaling by proteolysis. Cell 91: $443-446$

Sattler M, Liang H, Nettesheim D, Meadows RP, Harlan JE, Eberstadt M, Yoon HS, Shuker SB, Chang BS, Minn AJ, Thompson CB and Fesik SW (1997) Structure of $\mathrm{Bcl}-\mathrm{X}(\mathrm{L})$-Bak peptide complex - recognition between regulators of apoptosis. Science 275: 983-986

Schendel SL, Xie ZH, Montal MO, Matsuyama S, Montal M and Reed JC (1997) Channel formation by antiapoptotic protein Bcl-2. Proc. Natl. Acad. Sci. USA 94: 5113-5118

SchlesingerPH, Gross A, Yin XM, Yamamoto K, Saito M, Waksman Gand Korsmeyer SJ (1997) Comparison of the ion channel characteristics of proapoptotic Bax and antiapoptotic Bcl-2. Proc. Natl. Acad. Sci. USA. 94: 11357-11362

Schrank B, Gotz R, Gunnersen JM, Ure JM, Toyka KV, Smith AG and Sendtner M (1997) Inactivation of the survival motor neuron gene, a candidate gene for human spinal muscular atrophy, leads to massive cell death in early mouse embryos. Proc. Natl. Acad. Sci. USA. 94: 9920-9925

Sheehan JP, Swerdlow RH, Miller SW, Davis RE, Parks JK, Parker WD and Tuttle JB (1997a) Calcium homeostasis and reactive oxygen species production in cells transformed by mitochondria from individuals with sporadic Alzheimer's disease. J. Neurosci. 17: 4612-4622

Sheehan JP, Swerdlow RH, Parker WD, Miller SW, Davis RE and Tuttle JB (1997b) Altered calcium homeostasis in cells transformed by mitochondria from individuals with Parkinson's disease. J. Neurochem. 68: 1221-1233

Shimizu S, Eguchi Y, Kamiike W, Waguri S, Uchiyama Y, Matsuda H and Tsujimoto Y (1996) Retardation of chemical hypoxia-induced necrotic cell death by Bcl-2 and Ice inhibitors - possible involvement of common mediators in apoptotic and necrotic signal transductions. Oncogene 12: 2045-2050

Shindler KS, Latham CB and Roth KA (1997) Bax deficiency prevents the increased cell death of immature neurons in Bcl-X-deficient mice. J. Neurosci. 17: 31123119

Siklos L, Engelhardt J, Harati Y, Smith RG, Joo F, Appel SH (1996) Ultrastructural evidence for altered calcium in motor nerve terminals in amyotropic lateral sclerosis. Ann. Neurol. 39: 203-216

Swerdlow R, Parks J, Miller S, Tuttle J, Trimmer P, Sheehan J, Bennett JJ, Davis R and Parker WJ (1996) Origin and functional consequences of the complex I defect in Parkinson's disease. Ann. Neurol. 40:663-671
Tsujimoto Y, Finger LR, Tunis J, Nowell PC and Croce CM (1984) Cloning of the chromosomic breakpoint of neoplastic B cells with the $t(14 ; 18)$ chromosome translocation. Science 226: 1097-1099

Vekrellis K, McCarthy MJ, Watson A, Whitfield J, Rubin LL and Ham J (1997) Bax promotes neuronal cell death and is downregulated during the development of the nervous system. Development 124: 1239-1249

Vucic D, Kaiser WJ, Harvey AJ and Miller LK (1997) Inhibition of reaper-induced apoptosis by interaction with inhibitor of apoptosis proteins (IAPs). Proc. Natl. Acad. Sci. USA. 94: 10183-10188

Weibel D, Kreutzberg GW and Schwab ME (1995) Brain-derived neurotrophic factor (BDNF) prevents lesion-induced axonal die-back in young rat optic nerve. Brain Res. 679: 249-254

White RJ and Reynolds IJ (1996) Mitochondrial depolarization in glutamatestimulated neurons: an early signal specific to excitotoxin exposure. J. Neurosci. 16: $5688-5697$

White RJ and Reynolds IJ (1997) Mitochondria accumulate Ca2+ following intense glutamate stimulation of cultured rat forebrain neurones. J. Physiol. 498: 31-47

Wong PC, Pardo CA, Borchelt DR, Lee MK, Copeland NG, Jenkins NA, Sisodia SS, Cleveland DW and Price DL (1995) An adverse property of a familial ALS-linked SOD1 mutation causes motor neuron disease characterized by vacuolar degeneration of mitochondria. Neuron. 14: 1105-1116

Xiang JL, Chao DT and Korsmeyer SJ (1996) Bax-induced cell death may not require interleukin 1-beta- converting enzyme-like proteases. Proc. Natl. Acad. Sci. USA. 93: $14559-14563$

Yang E, Zha J, Jockel J, Boise LH, Thompson CB and Korsmeyer SJ (1995) Bad, a heterodimeric partner for $\mathrm{Bcl}-\mathrm{XL}$ and $\mathrm{Bcl}-2$, displaces $\mathrm{Bax}$ and promotes cell death. Cell. 80: 285-291

Yang J, Liu XS, Bhalla K, Kim CN, Ibrado AM, Cai JY, Peng TI, Jones DP and Wang XD (1997) Prevention of apoptosis by Bcl-2 - release of cytochrome c from mitochondria blocked. Science 275: 1129-1132

Yin XM, Oltval ZM and Korsmeyer SJ (1994) BH1 and BH2 domains of Bcl-2 are required for inhibition of apoptosis and heterodimerization with Bax. Nature 369 : $321-323$

Zou H, Henzel WJ, Liu XS, Lutschg A and Wang XD (1997) Apaf-1, a human protein homologous to C-Elegans ced-4, participates in cytochrome c-dependent activation of caspase-3. Cell 90: 405-413 